\title{
ASPECTS OF THE REGULATION OF CROSS-BORDER INSOLVENCY IN SOUTH AFRICA
}

\author{
Howard Chitimira \\ LLB LLM LLD \\ Associate Professor, Faculty of Law \\ North-West University, Mafikeng Campus
}

\begin{abstract}
SUMMARY
This article analyses the regulation of cross-border insolvency under the CrossBorder Insolvency Act 42 of $2000^{1}$ in order to examine the adequacy of such regulation as regards to the enforcement of insolvency proceedings in South Africa and other relevant jurisdictions. To this end, the paper provides an overview analysis of the regulation and/or enforcement of insolvency proceedings under the CrossBorder Insolvency Act. Moreover, where possible, the paper also provides a comparative analysis of selected aspects of the regulation and/or enforcement of insolvency proceedings under the Cross-Border Insolvency Act and those that are provided under the Insolvency Act 24 of 1936 and other related international instruments. This is done to expose the challenges and future prospects of the regulatory and enforcement framework under the Cross-Border Insolvency Act in South Africa.
\end{abstract}

\section{$1 \quad$ INTRODUCTION}

Various complexities and challenges have sometimes impeded the proper regulation of cross-border insolvency ${ }^{2}$ such as poor cooperation between affected countries and the inconsistent application of diverse cross-border insolvency approaches across different jurisdictions, including South Africa. ${ }^{3}$ Moreover, the lack of a more harmonised and adequate cross-border insolvency approach that is homogeneously enforced across different jurisdictions is another challenge faced by all countries to date. ${ }^{4}$ It is against this backdrop that this article discusses the regulation of cross-border insolvency under the Cross-Border Insolvency Act ${ }^{5}$ in order to examine the adequacy of such regulation as regards to the enforcement of insolvency proceedings in South Africa and other relevant jurisdictions such as Europe,

Hereinafter "the Cross-Border Insolvency Act".

The term "cross-border insolvency" is also known as "transnational insolvency" in many countries, including South Africa.

3 Olivier and Boraine "Some Aspects of International Law in South African Cross-border Insolvency Law” 2005 CILSA 373 373-383.

Ibid.

52 of 2000, hereinafter "the Cross-Border Insolvency Act". 
Australia, Asia and America. ${ }^{6}$ This is mainly done to expose the cross-border insolvency regulatory flaws in these jurisdictions and South Africa to highlight possible remedial measures in respect thereof. The aforesaid jurisdictions have relatively managed to obtain some considerable settlements in matters involving cross-border insolvency to date. ${ }^{7}$ It is hoped that South Africa could learn from such positive experiences from other jurisdictions. To this end, the article provides an overview analysis of the regulation and/or enforcement of insolvency proceedings under the CrossBorder Insolvency Act. ${ }^{8}$ Moreover, where possible, the paper also provides a comparative analysis of selected aspects of the regulation and/or enforcement of insolvency proceedings under the Cross-Border Insolvency Act and those that are provided under the Insolvency $\mathrm{Act}^{9}$ and other related international instruments. ${ }^{10}$ This is done to expose the challenges and future prospects of the regulatory and enforcement framework under the CrossBorder Insolvency Act in South Africa. ${ }^{11}$ Thereafter, some possible recommendations and concluding remarks are provided.

\section{THE DEFINITION OF SELECTED TERMS AND CONCEPTS}

Defining some key terms and concepts of cross-border insolvency in order to have a better understanding of the regulation of cross-border insolvency matters in South Africa and/or other jurisdictions is imperative. In this regard, as earlier stated, ${ }^{12}$ it is important to note that the term "cross-border insolvency" is also known as transnational insolvency law and it, inter alia, deals with the regulation of insolvency or bankruptcy proceedings of debtors $^{13}$ who reside in one jurisdiction ${ }^{14}$ while they have creditors or

6 See further Olivier and Boraine 2005 CILSA 383-395; Smith and Ailola "Cross-Border Insolvencies: An Overview of Some Recent Legal Developments" 1999 SA Merc LJ 192 203-209; Ailola "The UNCITRAL Model Law on Cross-Border Insolvency: Its Efficiency and Suitability as a Basis for a SADC Convention" 2000 Stell LR 215 222-224 and Smith "Some Aspects of Comity and the Protection of Local Creditors in Cross-Border Insolvency Law: South Africa and the United States Compared" 2002 SA Merc LJ 17 19-63.

See related discussion under par 4 below.

8 Franco "The Cross-Border Insolvency Act: Lifting the Barriers or Creating New Ones?" 2003 SA Merc LJ 27 33-42; Olivier and Boraine 2005 CILSA 383-395; Smith and Ailola 1999 SA Merc LJ 203-209; Smith 2002 SA Merc LJ 19-63.

924 of 1936, hereinafter "the Insolvency Act".

10 Such instruments are discussed in par 4 and 5 below. See further Zulman "Cross-Border Insolvency in South African Law" 2009 SA Merc LJ 804 808-817; Calitz "Some Thoughts on State Regulation of South African Insolvency Law" 2011 De Jure 290 292-318; Franco 2003 SA Merc LJ 33-42; Olivier and Boraine 2005 CILSA 383-395.

11 Stroebel Protocols as a Possible Solution to Jurisdiction Problems in Cross-Border Insolvencies (Unpublished LLM dissertation, North West University 2006) 16-26; Mouton The Competence of the Foreign Representative in Cross-Border Insolvency Matters: A Comparison between South Africa and Australia (Unpublished LLM dissertation, North West University 2013) 23-51; Ras The Future of the Cross-Border Insolvency Act 42 of 2000 in View of Developments Elsewhere (Unpublished LLM dissertation, North West University 2014) 19-36.

12 See remarks in fn 1 above.

13 The term "debtor" could include a person or partnership or the estate of person or partnership that owes something to a creditor or regarded as a debtor in the ordinary sense of the word. See $s$ of the Insolvency Act. 
property or assets and/or interests in property or assets in other jurisdictions. ${ }^{15}$ This suggests that a debtor in one country (local jurisdiction) could have his or her assets or property or estate in another country (foreign jurisdiction) and such assets or property or estate could be sequestrated by his or her creditors in that foreign jurisdiction when he becomes insolvent. Accordingly, the courts in the country where the insolvent is sequestrated only have jurisdiction to deal with the insolvent's assets situated within that particular country. In this case, any relevant foreign court that is located where the insolvent debtor has assets, businesses, property ${ }^{16}$ or interests in property could have the jurisdiction to institute and supervise such foreign cross-border insolvency proceedings. ${ }^{17}$ Moreover, the relevant foreign representative will have to apply for the recognition of foreign proceedings prior to dealing with insolvent's assets in South Africa. Notably, such proceedings could be instituted under the Cross-Border Insolvency Act ${ }^{18}$ in South Africa. In the same vein, the relevant local courts that are located where the insolvent debtor has assets, businesses, property or interests in property have the jurisdiction to sequestrate his or her estate for the benefit of the affected creditors under the Insolvency Act ${ }^{19}$ in South Africa. Nonetheless, the local courts have limited or no jurisdiction in foreign crossborder insolvency proceedings. In the same way, the foreign courts have limited or no jurisdiction in cross-border insolvency proceedings that are instituted in the local South African courts. Moreover, the recognition of foreign representatives and the equal treatment of both local and foreign creditors of the insolvent debtor during cross-border insolvency proceedings have remained problematic in South Africa ${ }^{20}$ and other jurisdictions such as

14 This is usually the local or domestic jurisdiction of such debtors and it is normally determined or granted to the relevant local or domestic courts that are situated in the area where the debtors are domiciled and/or where they have assets or property or businesses or related property interests.

15 Olivier and Boraine 2005 CILSA 373-375; Khumalo International Response to the UNCITRAL Model Law on Cross-border Insolvency Research paper presented within the LLM in International Business Law at the International Insolvency Institute, Vrije Universiteit, Amsterdam, The Netherlands, (July 2004) 1, 4-5 and 13-27; Westbrook "An Empirical Study of the Implementation in the United States of the Model Law on Cross Border Insolvency" 2013 American Bankruptcy LJ 247 247-259.

16 The term "property" means movable and immovable property of the debtor, which is found in South Africa and elsewhere. It also includes contingent interests in property other than the contingent interests of a fidei commissary heir or legatee. See $\mathrm{s} 2$ of the Insolvency Act.

17 Olivier and Boraine 2005 CILSA 373-375.

18 See ss 9-32, which, inter alia, deals with the access and recognition of foreign creditors and their representatives in the South African courts. These provisions, especially, ss 25-32 provides for the possible relief that is available to foreign creditors as well as the cooperation between the foreign representatives, foreign courts and the local courts.

19 See ss 9-12 of the Insolvency Act, which deals with the sequestration process. The local court usually grant such sequestration orders when the debtor has committed any of the acts of insolvency ( $\mathrm{s} 8$ of the Insolvency Act) and where the sequestration is deemed to be to the advantage of the affected creditors (ss 10(c) and 12(1)(c) of the Insolvency Act). The application for the sequestration of the debtor's estate can be instituted voluntarily by the debtor (ss 3, 4 and 6 of the Insolvency Act) or compulsorily by the creditor or any interested person (s 9 read with ss 10-12 of the Insolvency Act).

20 It is submitted that the relevant principles of private international law did not adequately resolve the challenges that were brought by cross-border insolvencies in South Africa. Consequently, the need for extra-territorial measures to eliminate such challenges and 
Europe, Australia, Asia and America to date. ${ }^{21}$ This and other factors indicate that there is still a great need for all the relevant stakeholders to come together and enact an adequate cross-border insolvency law such as a treaty or convention that is homogeneously and consistently enforced to regulate insolvency matters in all the jurisdictions. Furthermore, this could have been worsened by the fact that most cross-border insolvency regulations are merely model laws that are voluntarily adopted by member states.

Another key term is the "centre of main interests" (COMI). The COMI usually refers to the place where the debtor conducts his or her main interests and/or business activities regularly. ${ }^{22}$ This shows that a temporary or once off or irregular business activity and/or temporary place of such activity will not suffice. Likewise, a debtor's place where he or she carries his or her non-main interests or those activities that are not core to the relevant business will not suffice. ${ }^{23}$ The determination of the COMI varies from country to country and it also depends on the cross-border insolvency approach that is employed. In Australia, the cross-border insolvency matters are instituted as a single proceeding in the court where the debtor has its COMI. ${ }^{24}$ In Europe, the courts of the Member State that are situated in the area or place where the debtor has his or her COMI have jurisdiction to hear cross-border insolvency proceedings in respect of that debtor. ${ }^{25}$ When this occurs, such proceedings are regarded as the "main proceedings" for that cross-border insolvency matter. ${ }^{26}$ Accordingly, the law applicable to insolvency proceedings that are opened in the court of the Member State where the debtor's COMI is located is recognised under the European Union

regulate cross-border insolvencies was envisaged by the South African courts as early as 1902. See Ex parte Stegmann 1902 TS 40 54; Franco 2003 SA Merc LJ 27.

21 Wessels "Cross-Border Insolvency Law in Europe: Present Status and Future Prospects" 2008 PER 68 70-95; Anderson "The Cross-Border Insolvency Paradigm: A Defense of the Modified Universal Approach Considering the Japanese Experience" 2000 University of Pennsylvania Journal 679 687-779; Olivier and Boraine 2005 CILSA 377-395; Khumalo International Response to the UNCITRAL Model Law 8-27; Mohan "Cross-border Insolvency Problems: Is the UNCITRAL Model Law the Answer?" 2012 International Insolvency Review 199 201-223; Westbrook 2013 American Bankruptcy LJ 249-270; Mouton The Competence of the Foreign Representative in Cross-Border Insolvency Matters 59-72.

22 Mouton The Competence of the Foreign Representative in Cross-Border Insolvency Matters 10; Adams and Fincke "Coordinating Cross-Border Bankruptcy: How Territorialism Saves Universalism" 2008 Columbia Journal of European Law 43 60-61; Wessels 2008 PER 7380.

23 Adams and Fincke 2008 Columbia Journal of European Law 60-61; Wessels 2008 PER 73-80.

24 See ss $10 ; 15 ; 17 ; 22$ and other relevant provisions under Parts 1 and 2 of Australian CrossBorder Insolvency Act of 2008; Mouton The Competence of the Foreign Representative in Cross-Border Insolvency Matters 9-10; Adams and Fincke 2008 Columbia Journal of European Law 60-61; Wessels 2008 PER 73-80.

25 See article 3 of the European Union Regulation 2015/848 of the European Parliament and of the Council of 20 May 2015 on insolvency proceedings (EU Regulation 2015) revising the European Union Regulation on Insolvency proceedings 1346/2000 (EU Regulation 2000). Most of the provisions of the EU Regulation 2015 will come into force on 26 June 2017; Adams and Fincke 2008 Columbia Journal of European Law 60-61; Wessels 2008 PER 73-80.

26 See article 3(1) of the EU Regulation 2015. 
(EU) Regulation $2015 .{ }^{27}$ In this regard, it appears that the EU Regulation 2015 employs the territorial approach to determine the law that applies to cross-border insolvency proceedings that are instituted in the relevant court of the Member State. In other words, although the term COMI is universalistic in nature, territorialist presumptive rules and norms sometimes decide its determination. ${ }^{28}$ Moreover, the number of business deals that a debtor has with creditors (contact with creditors approach) is also employed in Europe to determine the COMI of that debtor. ${ }^{29}$ The headquarters approach or the debtor's main place of business is also employed to determine the COMI in Europe. ${ }^{30}$ In most instances, the COMl for corporations, companies and other juristic persons is presumed to be their main registered office. On the other hand, the COMI for individuals is usually presumed to be their principal place of business or place of habitual or permanent residence. In South Africa, the COMI is not expressly defined and/or provided for under the Cross-Border Insolvency Act. ${ }^{31}$ Nonetheless, foreign proceedings that are instituted in a court where the debtor has his or her COMI are recognised as foreign main proceedings or foreign non-main proceedings under the Cross-Border Insolvency Act. ${ }^{32}$ This approach is closely related to the United Nations Commission on International Trade Law (UNCITRAL) Model Law on Cross-border Insolvency ${ }^{33}$ that was adopted on 30 May 1997. Notably, both the UNCITRAL Model Law and the CrossBorder Insolvency Act are relatively based on the modified universal approach. ${ }^{34}$

Understanding the term "foreign court" is also crucial in respect of crossborder insolvency proceedings. In South Africa, a "foreign court" means a judicial or other authority competent to control or supervise foreign crossborder insolvency proceedings. ${ }^{35}$ This suggests that a court or competent authority in question must have actual judicial power rather than quasijudicial power to adjudicate upon such proceedings. Such powers are, inter alia, bestowed upon a foreign court that is located in the area where the

27 This entails that the law of the location of the court, which opened the insolvency proceedings at the debtor's COMI, is applicable to such proceedings. See article 3(2)-(4) and article 7 of the EU Regulation 2015.

28 Adams and Fincke 2008 Columbia Journal of European Law 60-61; Eastby "The Law of Unintended Consequences: The 2015 EU Insolvency Regulation and Employee Claims in Cross-Border Insolvencies" 2016 Chicago Journal of International Law 123 138-152. Wessels 2008 PER 78-80.

Ibid

31 See ss $1-8$.

32 Ss 16(3), 17(1) and (2) read with s 1(e), (f) and (g). See further Weideman and Stander "European and American Perspectives on the Choice of Law Regarding Cross-Border Insolvencies of Multinational Corporations - Suggestions for South Africa" 2012 PER 133 136-217.

33 United Nations General Assembly A CN 9/442, 19 December 1997, hereinafter "the UNCITRAL Model Law". See articles 16-20; the Guide to Enactment of the UNCITRAL Model Law: Annexure A 19; also see Zulman 2009 SA Merc LJ 813-817; Mouton The Competence of the Foreign Representative in Cross-Border Insolvency Matters 10-19 and 44-48; Ras The Future of the Cross-Border Insolvency Act 42 of 2000 19-35; Ailola 2000 Stell LR219-221.

34 Trichardt "The UNCITRAL Model Law on Cross-Border in Insolvency" 2002 Flinders Journal of Law Reform 95 106-123.

35 S 1 (d) of the Cross-Border Insolvency Act. 
debtor has his or her COMI. An almost identical definition and approach is employed under the UNCITRAL Model Law. ${ }^{36}$ However, a "foreign court" is not expressly defined under the EU Regulation $2015 .{ }^{37}$ On the other hand, the term "foreign main proceedings" is defined in South Africa as foreign cross-border insolvency proceedings that are instituted in a country or jurisdiction where the main interests (COMI) of the debtor are located. ${ }^{38}$ Thus, any other secondary insolvency proceedings that are instituted in a court where the debtor does not have a COMI do not constitute foreign main proceedings of that debtor. A similar definition and approach is employed under the UNCITRAL Model Law. ${ }^{39}$ Nevertheless, the term "foreign main proceedings" is not expressly defined in the EU Regulation 2015. ${ }^{40}$

Additionally, both the UNCITRAL Model Law ${ }^{41}$ and the South African Cross-Border Insolvency Act ${ }^{42}$ defined the term "foreign non-main proceedings" as foreign proceedings other than main proceedings that are instituted in a country or jurisdiction where the debtor has an "establishment" or non-transitory economic activities through human means as well as goods and services. Foreign non-main proceedings could refer to those crossborder insolvency proceedings that are instituted in a country other than the debtor's country of domicile, in respect of non-core business interests or activities that were previously executed in such country by that debtor. In contrast to this, the term "foreign non-main proceedings" is not expressly defined in the EU Regulation 2015. ${ }^{43}$ Despite this, other secondary insolvency proceedings are recognised in Europe. ${ }^{44}$ The term "establishment" carries the same meaning in South Africa, ${ }^{45}$ Europe $^{46}$ and the UNCITRAL Model Law, ${ }^{47}$ where it is defined as any place of operations where a debtor conducts or has conducted non-transitory economic activities through human means as well as goods and services. In relation to this, the author concurs with Weideman and Stander, ${ }^{48}$ who correctly submit that an

36 Article 2(e).

37 Nevertheless, a "court" is broadly defined as a judicial body of a Member State or any other competent body of a Member State empowered to open insolvency proceedings, or to confirm such opening, or to take decisions in the course of such proceedings. See article 2(6) of the EU Regulation 2015.

$38 \mathrm{~S} 1(\mathrm{e})$ of the Cross-Border Insolvency Act.

39 Article 2(b). See further Trichardt 2002 Flinders Journal of Law Reform 111-114; Clift "The UNCITRAL Model Law on Cross-Border Insolvency - A Legislative Framework to Facilitate Coordination and Cooperation in Cross-Border Insolvency" 2004 Tulane Journal of International Law and Comparative Law 307 325-326.

40 See article 2. Despite this, "insolvency proceedings" are listed in Annex A and other secondary insolvency proceedings are recognised in Europe. See article 2(4) read with articles 3(1); 5; 6 and 34-39 of the EU Regulation 2015.

41 Article 2(c). See further Clift 2004 Tulane Journal of International Law and Comparative Law 325-326.

$42 \mathrm{~S} 1(\mathrm{f})$ of the Cross-Border Insolvency Act.

43 See article 2.

44 See article 2(4) read with articles 6 and 34-39 of the EU Regulation 2015.

$45 \mathrm{~S} 1(\mathrm{c})$ of the Cross-Border Insolvency Act.

46 See article 2(10) of the EU Regulation 2015. This provision stipulates that a debtor must have conducted non-transitory economic activities through human means as well as goods and services at least three months prior to any request to open main insolvency proceedings against that debtor.

47 Article 2(f).

48 Weideman and Stander 2012 PER 190. 
objective test must be carefully employed to determine a debtor's "establishment". The mere availability or unavailability of the debtor's assets, property or interests in property in a certain place does not in itself indicate the existence or non-existence of his or her "establishment" in that jurisdiction. ${ }^{49}$ The relevant authorities must carefully establish that the debtor has some professional, corporate or other relevant economic activity that is permanent or non-transitory in nature before they dismiss or grant an "establishment" in respect of that debtor. ${ }^{50}$ In the same vein, the relevant authorities must carefully establish whether the debtor and/or his or her relevant employees conducted the aforesaid permanent economic activity. They must also investigate whether such economic activity is situated at the debtor's registered offices or place of business operations before they reject or accept his or her "establishment" 5

Both the UNCITRAL Model Law ${ }^{52}$ and the South African Cross-Border Insolvency $\mathrm{Act}^{53}$ have defined the term "foreign proceedings" as collective judicial or administrative proceedings (including interim proceedings) for insolvency that are conducted in other countries or jurisdictions for the purposes of placing the assets or affairs of the debtor under the control or supervision of a foreign court during reorganisation, business rescue or liquidation. Such proceedings must clearly have a collective nature that involves or benefits all the affected creditors indiscriminately. ${ }^{54}$ Additionally, a foreign court or a competent judicial authority must administer the stated proceedings in order to have a judicial or administrative nature for purposes of reorganisation, business rescue or liquidation of the affected insolvent person. ${ }^{55}$ In contrast to this, the term "foreign proceedings" is not expressly defined in the EU Regulation 2015. ${ }^{56}$ On the other hand, both the UNCITRAL Model Law ${ }^{57}$ and the South African Cross-Border Insolvency $\mathrm{Act}^{58}$ have defined the term "foreign representative" as any person or body appointed and/or authorised in foreign proceedings to administer the business rescue or liquidation of the debtor's affairs or assets or act as a representative of such proceedings. Only relevant persons such as trustees, insolvency practitioners and liquidators are empowered to have direct access to foreign cross-border insolvency proceedings under the both the UNCITRAL Model Law ${ }^{59}$ and the South African Cross-Border Insolvency Act. ${ }^{60}$ Nonetheless, foreign representatives are not automatically recognised

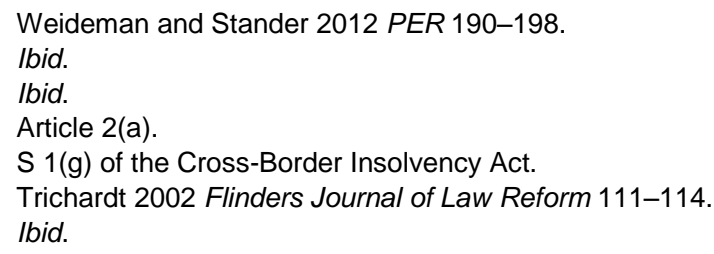

However, the term "collective proceedings" is defined as proceedings which include all or a significant part of a debtor's creditors, provided that, in the latter case, the proceedings do not affect the claims of creditors which are not involved in them. See article 2(1) of the EU Regulation 2015.

57 Article 2(d).

58 S $1(\mathrm{~h})$ of the Cross-Border Insolvency Act.

59 Articles 9-14.

60 Ss 5 and 7 read with ss 9-14 of the Cross-Border Insolvency Act; see further Clegg $v$ Priestley 1985 (3) SA 950 (W); Priestley v Clegg 1985 (3) SA 955 (T); Ward v Smith: In re 
and granted access to foreign proceedings because they are obliged to apply to the court for recognition of the foreign proceedings in which they have been appointed to represent or act on behalf of the relevant creditors. ${ }^{6}$ On the one hand, the term "foreign representative" is not expressly defined in the EU Regulation 2015. ${ }^{62}$ However, the role of a related term namely the "insolvency practitioner" is briefly enumerated in the EU Regulation 2015.

\section{THE RATIONALE FOR CROSS-BORDER INSOLVENCY REGULATION}

Owing to international trade and the adoption of efficient measures to promote better economic movement of goods and services in many jurisdictions, it is now very common for debtors from one country to have assets or property and/or interests in property in several other jurisdictions. This has created several challenges regarding the rights and equal protection of all the foreign creditors of insolvent debtors in many jurisdictions. ${ }^{64}$ Accordingly, it has become crucially essential to enact adequate laws that regulate cross-border insolvency matters from one jurisdiction to the other in order to protect such foreign creditors. Such crossborder insolvency laws are inevitably important as they enable both the insolvent debtors and the foreign creditors to enforce their rights and to actively take part in insolvency proceedings that are instituted in different countries. ${ }^{65}$ This also enables the foreign creditors who take part in such proceedings to have jurisdiction over the insolvent debtor's estate, assets and/or property. Robust cross-border insolvency regulation provides the foreign courts, domestic courts and other stakeholders with the relevant recognition as well as the opportunity to effectively cooperate and coordinate cross-border insolvency proceedings. Put differently, the effective enforcement of both national and international cross-border insolvency laws will combat the challenges associated with the coordination of such laws. ${ }^{66}$

Gurr v Zambia Airways Corporation Ltd 1998 (3) SA 175 (SCA); Ex parte Palmer NO: In re Hahn 1993 (3) SA 359 (C) 362 I-J; Bekker NO v Kotzé 1996 (4) SA 1287 (Nm); 1996 (4) SA 1293 (Nm); Sackstein NO v Proudfoot (Pty) Ltd [2003] 2 All SA 59 (SCA); Moolman v Builders and Developers (Pty) Ltd 1990 (1) SA 954 (AD); Singularis Holdings Ltd $v$ PricewaterhouseCoopers (Bermuda) [2014] UKPC 36 (10 November 2014); [2015] 2 WLR 971 , on the rights of foreign creditors, foreign representatives and the recognition of foreign insolvency proceedings.

61 Article 15(1) of the UNCITRAL Model Law; s 15(1) of the Cross-Border Insolvency Act. See further Ras The Future of the Cross-Border Insolvency Act 42 of 2000 26-30; Calitz and Burdette "The Appointment of Insolvency Practitioners in South Africa: Time for Change?" 2006 TSAR 721 733-751; Mouton The Competence of the Foreign Representative in Cross-Border Insolvency Matters 12-17; Zulman 2009 SA Merc LJ 816-817; Adams and Fincke 2008 Columbia Journal of European Law 76-81; Franco 2003 SA Merc LJ 33-38; Loubser "An International Perspective on the Regulation of Insolvency Practitioners" 2007 SA Merc LJ 123 124-139.

62 See article 2.

63 See article 2(5) read with articles $19-22 ; 41 ; 43 ; 64 ; 69$.

64 Khumalo International Response to the UNCITRAL Model Law 4.

65 Such countries will only have the jurisdiction to hear cross-border insolvency matters if their relevant courts are situated in the place where the insolvent debtor has his or her COMI.

66 Khumalo International Response to the UNCITRAL Model Law 4. 
In this regard, the author concurs with Adams and Fincke, ${ }^{67}$ who correctly submit that the coordination of cross-border insolvency proceedings has been sometimes marred by the lack of binding international insolvency rules, policies and laws that are uniformly enforced in all jurisdictions. Accordingly, enacting binding international cross-border insolvency laws that are uniformly and consistently enforced in all jurisdictions could resolve the uncertainty associated with the preferent and secured claims of both domestic and foreign creditors of the insolvent debtor. Moreover, binding international cross-border insolvency laws that are uniformly and consistently enforced in all jurisdictions could provide some certainty on the application of the key concepts of comity, equity, and convenience by the relevant courts. ${ }^{68}$ Thus, in other words, the adequate regulation of crossborder insolvency is vitally needed to improve the adjudication, cooperation, information sharing and coordination of all cross-border insolvency proceedings in South Africa and other countries. ${ }^{69}$

Additionally, the adequate regulation of cross-border insolvency will give rise to the equal recognition and protection of the debtor's domestic and foreign creditors as well as other interested parties that are domiciled in other jurisdictions. ${ }^{70}$ In this regard, the equal recognition and protection of the debtor's creditors could be realised by the adoption of regional and international cross-border insolvency rules and regulations, directives, conventions, treaties or other relevant best practice standards that are homogeneously and consistently enforced in all jurisdictions. ${ }^{71}$ Moreover, such equal protection of the debtor's creditors and other interested parties could ultimately promote international investment and trade across all the relevant jurisdictions. ${ }^{72}$

Globalisation and modern technological innovations have propelled several individuals and companies to conduct cross-broader businesses and to own property in many jurisdictions. However, these developments have sometimes caused regulatory problems to the relevant authorities, especially, when the debtor becomes insolvent or faces diverse sequestration and/or business rescue proceedings in other countries where he has property or businesses. Put differently, the significant increase in the number of cross-border insolvency cases in recent years justifies the ineluctable need for robust insolvency laws and related approaches to homogeneously regulate cross-border insolvency proceedings in different countries. ${ }^{73}$

Adams and Fincke 2008 Columbia Journal of European Law 43.

68 Franco 2003 SA Merc LJ 29.

69 LoPucki "Cooperation in International Bankruptcy: A Post-Universalist Approach" 1999 Cornell LR 696 750-762; Fletcher The Law of Insolvency (1990) 27-30.

70 Khumalo International Response to the UNCITRAL Model Law 4-11; Temperman The Judiciary's Discretion in Sequestration Applications (Unpublished LLM dissertation, University of Pretoria 2014) 36-45.

71 Mohan 2012 International Insolvency Review 219-223.

72 Mohan 2012 International Insolvency Review 199-200, 219-223; Weideman and Stander 2012 PER 133-134.

73 Such cases include Rubin v Eurofinance SA [2013] 1 AC 236; Re Saad Investments Co Ltd and Singularis Holdings Ltd [2013] BDA LR 28; PwC v Saad Investments Company Ltd [2013] BDA LR 82; Singularis Holdings Ltd v PricewaterhouseCoopers (Bermuda) [2014] 
As stated above, the lack of binding international insolvency laws that are uniformly enforced in all jurisdictions has, directly and indirectly, caused many countries to develop and utilise their own domestic laws to regulate cross-border insolvency proceedings. ${ }^{74}$ While this is commendable, it has often resulted in the adoption of confusingly diverse and inadequate approaches towards the regulation of cross-border insolvency proceedings in many jurisdictions. For instance, in South Africa, the Insolvency Act and the common law are applicable to domestic insolvency matters that are not covered under the Cross-Border Insolvency Act. Likewise, countries in different jurisdictions such as the United States of America (USA), Australia, and the United Kingdom (UK) have also enacted their own national insolvency laws to regulate cross-border insolvency proceedings. ${ }^{75}$ In light of this, it is submitted that all countries must carefully enact their national insolvency legislation in line with international insolvency standards to effectively combat cross-border insolvency regulatory problems in the future. Countries must also develop and adopt adequate uniform cross-border insolvency approaches that are consistently enforced all jurisdictions to enhance the adjudication of cross-border insolvency proceedings. ${ }^{76}$

Furthermore, adequate cross-border insolvency regulation could give rise legal certainty across all the jurisdictions. ${ }^{77}$ Lastly, adequate cross-border insolvency regulation will enhance and promote the timeous settlements of cross-border insolvency matters in South Africa and other countries. ${ }^{78}$

\section{SELECTED GENERAL APPROACHES TO CROSS- BORDER INSOLVENCY REGULATION}

Various national and international approaches to cross-border insolvency regulation have been adopted in many countries and jurisdictions such as Europe, Australia, Asia and America to date. ${ }^{79}$ For instance, international regulations have been adopted to police cross-border insolvency matters in many jurisdictions as early as 1679 to date. ${ }^{80}$ Nevertheless, a majority of cross-border insolvency treaties and conventions that were concluded in

UKPC 36 (10 November 2014); [2015] 2 WLR 971. See further Hammer and McClintock "Understanding Chapter 15 of the United States Bankruptcy Code: Everything You Need to Know about Cross-Border Insolvency Legislation in the United States" 2008 Law and Business Review of the Americas 257 258-259; Tait "The Train Now Departing: Insolvency and Cross-Border Recognition Reform - Hong Kong's Missed Opportunity?" 2015 Corporate Rescue and Insolvency Journal 143; Smith "Assisting Foreign Insolvency Practitioners in Cross-Border Insolvency: Some Foreign Insights into South African Law Singularis Holdings Ltd $v$ Pricewaterhouse Coopers (Bermuda) [2014] UKPC 36 (10 November 2014), [2015] 2 WLR 971" 2016 Obiter 167 168-186.

74 Stroebel Protocols as a Possible Solution to Jurisdiction Problems 3, 16-27; Mouton The Competence of the Foreign Representative in Cross-Border Insolvency Matters 23-51.

75 Ras The Future of the Cross-Border Insolvency Act 42 of 2000 36-58; Smith 2002 SA Merc LJ 19-63.

76 Clift 2004 Tulane Journal of International Law and Comparative Law 308-315.

77 Ibid.

78 Khumalo International Response to the UNCITRAL Model Law 6-8; Temperman The Judiciary's Discretion in Sequestration Applications 36-45.

79 Clift 2004 Tulane Journal of International Law and Comparative Law 311-333.

80 Trichardt 2002 Flinders Journal of Law Reform 101-103. 
most jurisdictions have been bilateral rather than universal in nature. ${ }^{81}$ Likewise, some cross-border insolvency treaties and conventions that were concluded in other jurisdictions are regional rather than universal in nature. ${ }^{82}$ Moreover, the main shortcoming of all treaties (whether universal or otherwise) and conventions is that they are only enforceable to regulate cross-border insolvency matters that occur between the countries that ratified them. ${ }^{83}$ Notably, South Africa has not yet concluded or ratified any treaty or convention on cross-border insolvency regulation. ${ }^{84}$ It is crucial to note that when South Africa concludes or ratifies such treaties or conventions in the future, the requirements of such treaties or conventions will only become enforceable between the concerned parties if they are enacted into the relevant law in terms of the Constitution. ${ }^{85}$ Furthermore, if the provisions of the Cross-Border Insolvency Act are conflicting with the requirements of such treaties or conventions, the requirements of those treaties or conventions will prevail. ${ }^{86}$

Inter-state or regional cross-border insolvency laws, rules, principles, guidelines and regulations have also been adopted to regulate cross-border insolvency matters in some jurisdictions such as Europe, Asia and America. This approach is mainly targeted at combating cross-border insolvency problems in a particular region between like-minded member states. For instance, the EU Regulation 2000 on cross-border insolvency proceedings, which the European Union (EU) adopted on 29 May 2000 to bind all EU member states except Denmark, is a case in point. ${ }^{87}$ The EU Regulation 2000 repealed and replaced the European Convention on Insolvency Proceedings of 23 November $1995 .{ }^{88}$ As earlier stated, ${ }^{89}$ the EU Regulation

81 Notable examples of such bilateral cross-border insolvency treaties include the FrancoSwiss Convention of 1869, the Franco-Belgium Convention of 1899, the Franco-Italian Convention of 1930, the Franco-Monaco Convention of 1950 and the Franco-Austrian Convention of 1979; see further Trichardt 2002 Flinders Journal of Law Reform 101.

82 Notable examples of such regional cross-border insolvency treaties include the Montevideo Treaty of 1889; Bustamante Code of 1928 which was adopted by 15 Latin American countries; Nordic Convention of 1933 which was adopted by Denmark, Finland, Iceland, Norway and Sweden; the Organisation for the Harmonisation of Business Law in Africa which is also known as the Organisation pour l'Harmonisation en Afrique du Droit des Affaires (OHADA) of 1995 which was adopted by 17 West and Central African countries. See further Mohan 2012 International Insolvency Review 201-223; LoPucki 1999 Cornell LR 696-753; Trichardt 2002 Flinders Journal of Law Reform 101-128; Howcroft "Universal vs Territorial Models for Cross-Border Insolvency: The Theory, the Practice, and the Reality that Universalism Prevails" 2007-2008 UC Davis Business LJ 366 368-386.

83 The non-universalistic nature of treaties and conventions restricts cross-border insolvency regulation to countries that are parties or signatories to such treaties and conventions. This implies that cross-border insolvency proceedings that are conducted in other non-signatory countries where the debtor has property and creditors remains unregulated. See Mohan 2012 International Insolvency Review 201-223.

84 Olivier and Boraine 2005 CILSA 377-378, 384; Ras The Future of the Cross-Border Insolvency Act 42 of 2000 25; Mouton The Competence of the Foreign Representative in Cross-Border Insolvency Matters 23.

85 S 231(4) of the Constitution of South Africa, 1996 (hereinafter "the Constitution").

86 S 3 of the Cross-Border Insolvency Act; see further Olivier and Boraine 2005 CILSA 377378, 384; Ras The Future of the Cross-Border Insolvency Act 42 of 200025.

87 See further Olivier and Boraine 2005 CILSA 377-378, 384; Weideman and Stander 2012 PER 134-135; Khumalo International Response to the UNCITRAL Model Law 26-27.

88 Khumalo International Response to the UNCITRAL Model Law 26.

89 See par 2 above. 
2000 was recently revised by the EU Regulation 2015 to, inter alia, improve the regulation of cross-border insolvency proceedings in the EU. On the contrary, no such inter-state or regional cross-border insolvency laws, rules, principles, guidelines and regulations have been adopted in the BRICS, the Southern African Development Community (SADC) and the African Union (AU) to date. ${ }^{90}$ Additionally, South Africa has not yet ratified any inter-state or regional cross-border insolvency laws to date.

Cross-border insolvency protocols are sometimes employed to tackle transnational insolvency problems in some jurisdictions. Protocols are usually private agreements between the affected parties in international insolvency proceedings that provide a specific set of solutions to crossborder insolvency problems on a case by case basis. ${ }^{91}$ Put differently, according to Stroebel, protocols "are legal arrangements between two or more courts in different jurisdictions, governing the way in which assets in the different countries will be dealt with". ${ }^{92}$ Protocols are normally used to enforce and protect the rights of the affected parties in cross-border insolvency proceedings without disregarding the sovereignty of the relevant courts. In other words, the enforcement of protocols does not necessarily override the independent jurisdiction of the relevant courts in a country in respect of cross-border insolvency proceedings that are pending in the courts in other countries. ${ }^{93}$ In most instances, protocols are used as legal instruments that determine appropriate measures that will be employed by the courts in different jurisdictions in order to effectively coordinate and finalise their cross-border insolvency proceedings. Nonetheless, the effective enforcement of cross-border insolvency protocols is contingent upon the relevant courts in different countries' timeous coordination and consistent cooperation to finalise such proceedings. ${ }^{94}$ Protocols have been successfully employed in countries such as the USA and Canada. ${ }^{95}$ In light of this, it is hoped that South Africa will consider utilising protocols to complement the provisions of the Cross-Border Insolvency Act.

Furthermore, the principles of private international law are sometimes employed to combat cross-border insolvency problems in South Africa and

90 Smith and Ailola 1999 SA Merc LJ 203-209; Ailola 2000 Stell LR 222-225.

91 Trichardt 2002 Flinders Journal of Law Reform 105-106.

92 Stroebel Protocols as a Possible Solution to Jurisdiction Problems 27-33.

93 Stroebel Protocols as a Possible Solution to Jurisdiction Problems 30.

94 Stroebel Protocols as a Possible Solution to Jurisdiction Problems 28.

95 The courts successfully enforced protocols in concurrent insolvency proceedings that were instituted in cases such as Re Maxwell Communications Corporation p/c (No 2) Barclays Bank p/c v Homan [1992] BCC757 (ChD); Maxwell Communications Corporation v Societe Generale (In re Maxwell Communications Corporation) (1994) Bankr SDNY 170 BR 800; affd 186 BR 807 (SDNY 1995); affd 93 F3d 1036 (2nd Cir 1996); In re Olympia and York Developments Ltd (1996) 43 Can Bankr Rep (3d) 111 (Ont); In re Olympia and York Developments Ltd (1997) 45 Can Bankr Rep (3d) 100 (Ont); In re Olympia and York Developments Ltd (1997) Can Bankr Rep 45 (3d) 85 (Ont); Nakash v Zur (In re Nakash) (1996) Bankr SDNY 190 BR 763. Protocols were further successfully employed in landmark cases involving the Lehman Brothers, Bernard Madoff and Nortel Networks in 2009. See Trichardt 2002 Flinders Journal of Law Reform 105-106; Stroebel Protocols as a Possible Solution to Jurisdiction Problems 30-33; Mohan 2012 International Insolvency Review 222223.

96 This approach could relatively enable the fast; flexible and timeous settlements of crossborder insolvency matters that are instituted between South Africa and other countries. 
other countries. These principles have a strong influence on the development and enactment of national insolvency laws in different jurisdictions, especially, when they are incorporated into such laws. ${ }^{97}$

The territorial theory or approach stipulates that each country must apply its own national insolvency laws in relation to the debtor's assets, liabilities and creditors that are located within its relevant courts' jurisdiction. Consequently, no extra-territorial application of insolvency laws is allowed under the territorial approach. ${ }^{98}$ Thus, the territorial approach indirectly protects local creditors by, inter alia, ensuring that such creditors' claims are paid or preferred first before those of other foreign creditors of the same insolvent debtor. Put differently, any affected country will seize or apply to seize the local assets of the insolvent debtor in order to benefit and distribute them amongst the local creditors. ${ }^{99}$ It is further submitted that this status quo is evident in most cross-border insolvency proceedings involving the sequestration of the insolvent debtor's estate in many jurisdictions. ${ }^{100}$ Proponents of the territorial approach submit that it is relatively predictable since it is mainly targeted at benefiting local creditors while respecting the sovereignty of the relevant courts. They also argue that the territorial approach could be easier to manage, as local creditors are more likely to cooperate since they will be located in the same jurisdiction. ${ }^{101}$ Nonetheless, the main disadvantage of the territorial approach is that it overlooks the rights of the foreign creditors of the insolvent debtor during cross-border insolvency proceedings. In other words, the territorial approach does not treat the local and foreign creditors of the debtor equally in such proceedings. Moreover, the territorial approach could encourage the insolvent debtor to engage in compromise or other related conduct with local creditors for their own benefit at the expense of the foreign creditors. Additionally, there are more costs involved in the coordination of crossborder insolvency proceedings that instituted in different jurisdictions. ${ }^{102}$ Notably, in South Africa, the Cross-Border Insolvency Act does not seem to follow the territorial approach.

The cooperative territorial approach is also employed to resolve crossborder insolvency problems in other jurisdictions. This approach allows each country to apply its own national insolvency laws in relation to the debtor's assets, liabilities and creditors that are located within its courts' jurisdiction. Thereafter, each court appoints a representative that cooperates with the representatives that are designated from other jurisdictions in order to

97 Mouton The Competence of the Foreign Representative in Cross-Border Insolvency Matters 23-25.

98 Stroebel Protocols as a Possible Solution to Jurisdiction Problems 4; Mouton The Competence of the Foreign Representative in Cross-Border Insolvency Matters 28-29.

99 Stroebel Protocols as a Possible Solution to Jurisdiction Problems 4; Anderson 2000 University of Pennsylvania Journal 697-700; Trichardt 2002 Flinders Journal of Law Reform 99-100.

100 Mouton The Competence of the Foreign Representative in Cross-Border Insolvency Matters 28-29; Stroebel Protocols as a Possible Solution to Jurisdiction Problems 4.

101 LoPucki "The Case for Cooperative Territoriality in International Bankruptcy" 2000 Michigan LR 2216 2219-2251; Adams and Fincke 2008 Columbia Journal of European Law 55-59; Howcroft 2007-2008 UC Davis Business LJ 370-386.

102 Adams and Fincke 2008 Columbia Journal of European Law 55-59; Howcroft 2007-2008 UC Davis Business LJ 370-386. 
ensure that all the debtor's creditors within the representatives' jurisdiction have some benefits. ${ }^{103}$ Each representative determines whether or not such benefits will be available for creditors in his or her own jurisdiction. ${ }^{104}$ Although the cooperative territorial approach is relatively good in that it encourages representatives of creditors from different jurisdictions to have recognition and to claim from the debtor's estate, it carries the same disadvantages as the territorial approach. In light of this, it is interesting to note that the cooperative territorial approach is sometimes employed by the South African courts since they are obliged to cooperate with, recognise and grant access to foreign representatives of the debtor's creditors in respect of cross-border insolvency proceedings.

The universalist approach is another option available to all the persons affected by cross-border insolvency problems. This approach provides that cross-border insolvency matters be decided under single proceedings in a single court (home country court) where the debtor is resident or has its COMI. The aforesaid court is empowered to apply its own local insolvency laws in respect of the sequestration of the debtor's estate. The decision of the home country court binds the courts and relevant persons in other jurisdictions. Thereafter, an appointed liquidator distributes the debtor's local and foreign proceeds to all creditors. ${ }^{106}$ The main advantage of the universal approach is that it provides same rights and treatment to all the creditors of the debtor in cross-border insolvency proceedings. The universalist approach also enables the creditors to realise more proceeds since the sequestration and administration of the debtor's estate is done under relatively cost-effective single proceedings in one court. Over and above, such single proceedings provide a better platform for the debtor's multinational companies that require better coordination of assets in different countries for reorganisation and/or business rescue procedures. ${ }^{107}$ Additionally, proponents of the universalistic approach submit that the distribution of assets through a single court will give rise to fairer and more predictable distributions to both domestic and foreign creditors of the insolvent debtor. ${ }^{108}$ The main disadvantage of the universalistic approach is

103 Mouton The Competence of the Foreign Representative in Cross-Border Insolvency Matters 29-30.

104 Mouton The Competence of the Foreign Representative in Cross-Border Insolvency Matters 29-30; Lechner "Waking from the Jurisdictional Nightmare of Multinational Default: The European Council Regulation on Insolvency Proceedings" 2002 Arizona Journal of International and Comparative Law 975 982-986; LoPucki 1999 Cornell LR 742-760; Adams and Fincke 2008 Columbia Journal of European Law 55-59; Anderson 2000 University of Pennsylvania Journal 697-698.

105 Ss 9-14 of the Cross-Border Insolvency Act; see further Mouton The Competence of the Foreign Representative in Cross-Border Insolvency Matters 30.

106 Mouton The Competence of the Foreign Representative in Cross-Border Insolvency Matters 26-27; Adams and Fincke 2008 Columbia Journal of European Law 49-53; Anderson 2000 University of Pennsylvania Journal 687-692.

107 Howcroft 2007-2008 UC Davis Business LJ 370-371; Westbrook "Universalism and Choice of Law" 2005 Penn State International LR 625 626-637.

108 LoPucki 1999 Cornell LR 704-718; Rasmussen "A New Approach to Transnational Insolvencies" 1997 Michigan Journal of International Law 1 10-26; Rasmussen "Resolving Transnational Insolvencies through Private Ordering" 2000 Michigan LR 1 4-30; Westbrook "Theory and Pragmatism in Global Insolvencies: Choice of Law and Choice of Forum" 1991 American Bankruptcy LJ 457461. 
that the sovereignty of the courts in other jurisdictions might be compromised since only the home country court has jurisdiction over the debtor's cross-border insolvency proceedings. It could be argued that South Africa does not follow a pure universalistic approach since the Cross-Border Insolvency Act provides that: (a) foreign creditors and their representatives have limited jurisdiction in South African cross-border insolvency proceedings, and (b) its provisions only apply to countries designated by the Minister in the Government Gazette.

Affected persons may rely on a modified universalist approach to address cross-border insolvency problems in their respective jurisdictions. The modified universalist approach allows affected countries to identify the most relevant jurisdiction to adjudicate upon cross-border insolvency proceedings. Thus, the home country court will not have automatic jurisdiction to adjudicate upon cross-border insolvency matters, as other countries will vote to decide, cooperate and support the most relevant court to commence such proceedings. ${ }^{110}$ Unlike pure universalist approach, modified universalist approach empowers other foreign courts apart from the home country court to institute cross-border insolvency proceedings wherever the debtor has assets and/or creditors. ${ }^{111}$ Such auxiliary proceedings are advantageous in that they promote the sovereignty of both foreign and domestic courts by granting them the discretion to objectively protect the interests of local creditors when distributing the debtor's assets. ${ }^{112}$ The modified universalist approach provides affected countries with excellent opportunities to cooperate with each other for the purposes of enforcing their respective cross-border insolvency legislation. Nonetheless, this approach encourages multiple cross-border insolvency proceedings, which in turn are expensive and results in little proceeds to be realised by the creditors. The modified universalist approach worsens the confusion associated with the identification of the home country and the debtor's COMI. Interestingly, as earlier stated, ${ }^{113}$ the South African Cross-Border Insolvency Act is relatively based on the UNCITRAL Model Law that in turn is reportedly based on the modified Universalist approach. ${ }^{114}$

The UNCITRAL Model Law can be utilised to tackle cross-border insolvency challenges in other countries. The UNCITRAL Model Law is merely a legislative text (soft law) which outlines the measures that could be incorporated by enacting states or countries into their national insolvency legislation to curb cross-border insolvency problems. ${ }^{115}$ Consequently, it is

109 Ss 2(2) and 10 of the Cross-Border Insolvency Act.

110 LoPucki 1999 Cornell LR 725; Mouton The Competence of the Foreign Representative in Cross-Border Insolvency Matters 28; Adams and Fincke 2008 Columbia Journal of European Law 50-55; Westbrook "The Lessons of Maxwell Communication" 1996 Fordham LR2531 2533.

111 Adams and Fincke 2008 Columbia Journal of European Law 50-52.

112 Anderson 2000 University of Pennsylvania Journal 690-692; Mouton The Competence of the Foreign Representative in Cross-Border Insolvency Matters 28; Howcroft 2007-2008 UC Davis Business LJ 370-371.

113 See par 2 above.

114 Perkins "A Defense of Pure Universalism in Cross-Border Corporate Insolvencies" 2000 NY University Journal of Int. Law and Politics 787 791; Olivier and Boraine 2005 CILSA 387.

115 Mouton The Competence of the Foreign Representative in Cross-Border Insolvency Matters 6-22. 
not automatically binding on enacting states or countries. This has sometimes negatively enabled enacting states or countries to excessively modify and/or omit other key provisions of the UNCITRAL Model Law. The UNCITRAL Model Law is, inter alia, aimed at providing effective measures for the promotion of cooperation between the courts and other relevant authorities in different countries on matters involving cross-border insolvency. ${ }^{116}$ This is usually done by granting representatives of foreign creditors' access to local (domestic) courts in all cross-border insolvency matters. ${ }^{117}$ The UNCITRAL Model Law is also aimed at promoting uniformity and legal certainty that in turn enhances trade, investment, fair administration of the debtor's estate and equal protection of all the affected creditors. ${ }^{118}$ Ultimately, this enables the courts, creditors and other interested persons to protect the debtor's estate assets from being destroyed. Additionally, the UNCITRAL Model Law promotes the utilisation of crossborder business rescue proceedings of the insolvent debtor's multi-national companies in a bid to protect investments and employees' jobs. ${ }^{119}$ Over 19 countries have adopted the UNCITRAL Model Law to date, including South Africa. ${ }^{120}$ Notably, the UNCITRAL Model Law is only applicable where: (a) assistance is sought in a country ${ }^{121}$ by a foreign court or representative in connection with foreign insolvency proceedings; or (b) assistance is sought in a foreign country in connection with insolvency proceedings under the national insolvency laws of the enacting country; ${ }^{122}$ or (c) foreign insolvency proceedings and insolvency proceedings under the national insolvency laws of the enacting country in respect of the same debtor takes place concurrently; or (d) creditors or other interested persons in a foreign country have requested the commencement of, or participation in insolvency proceedings under the national insolvency laws of the enacting country. ${ }^{123}$ Almost identical provisions are found in the Cross-Border Insolvency Act. ${ }^{124}$ Nonetheless, the provisions that exempt banks, insurance companies and other entities from the application of the UNCITRAL Model Law ${ }^{125}$ in the enacting country are not found in the Cross-Border Insolvency Act. ${ }^{126}$

116 Articles 25-27 of the UNCITRAL Model Law.

117 Articles 9-24 of the UNCITRAL Model Law.

118 Preamble of the UNCITRAL Model Law.

119 Adams and Fincke 2008 Columbia Journal of European Law 59-70; Report on the Working Group on Insolvency Law on the Work of Its Twentieth Session (1996) 3 UN Doc A/CN 9/433; [1999] XXVIII YB UNCITRAL UN Doc A/CN 9/SER.A/1997; Clift 2004 Tulane Journal of International Law and Comparative 315; Trichardt 2002 Flinders Journal of Law Reform 108-125.

120 Howcroft 2007-2008 UC Davis Business LJ 413-415; Mohan 2012 International Insolvency Review 201-223; Khumalo International Response to the UNCITRAL Model Law 8-13; Ras The Future of the Cross-Border Insolvency Act 42 of 2000 20-36; Clift 2004 Tulane Journal of International Law and Comparative Law 315-339; Anderson "Testing the Model Soft Law Approach to International Harmonisation: A Case-Study Examining the UNCITRAL Model Law on Cross-Border Insolvency" 2004 Australian Year Book of International Law 14-11.

121 This is a debtor's country of domicile or a country and/or state that enacted its insolvency laws based on the UNCITRAL Model Law.

122 A country that enacted its insolvency laws based on the UNCITRAL Model Law.

123 Article 1(1) of the UNCITRAL Model Law.

124 S 2(1).

125 Article 1(2) of the UNCITRAL Model Law.

126 S 2(2)-(5) 
The secondary insolvency approach is also employed to enforce crossborder insolvency laws in some jurisdictions. This approach entails that local or national insolvency proceedings must have or seek to have an extraterritorial effect and the local courts must give limited assistance to foreignoriginated insolvency cases.

Lastly, national insolvency laws at statutory or common law level can be employed to address cross-border insolvency problems in many countries including South Africa.

\section{THE REGULATION OF CROSS-BORDER INSOLVENCY IN SOUTH AFRICA}

As stated earlier, ${ }^{128}$ the Cross-Border Insolvency Act and the Insolvency Act regulates cross-border and national insolvency matters respectively. ${ }^{29}$ In addition, common law may be employed to deal with both cross-border and national insolvency matters where statutory provisions are silent, inapplicable or inadequate. However, notwithstanding the fact that South Africa has several key regional and international trading partners, it is yet to ratify a treaty or convention on cross-border insolvency regulation. ${ }^{130}$ Thus, it relies on the Cross-Border Insolvency Act and the common law to regulate cross-border insolvency matters.

Roman law, Roman-Dutch law, English law and court judgments influence the South African common law. ${ }^{131}$ Moreover, the South African common law insolvency regulation is mostly based on the relevant principles of private international law (conflict of laws), especially, with regard to the status and location of the property in South Africa. ${ }^{132}$ The South African common law rules on cross-border insolvency are also governed by the principles of comity, ${ }^{133}$ convenience and equity. ${ }^{134}$ In other words, where the principles of comity, convenience and equity apply, the South African High Courts have

127 The secondary insolvency approach is usually employed in Switzerland; see Anderson 2000 University of Pennsylvania Journal 692-694.

128 See related discussion in par 2 above.

129 Notably, some national insolvency matters are regulated under the Long-term Insurance Act 52 of 1998 (Long-term Insurance Act), the Alienation of Land Act 68 of 1981 (Alienation of Land Act), and corporate insolvency provisions of the Companies Act 61 of 1973 (Companies Act 1973) which were retained by the Companies Act 71 of 2008 (Companies Act 2008). See Zulman 2009 SA Merc LJ 806-809.

130 Olivier and Boraine 2005 CILSA 377-378, 384; see related remarks in par 4 above.

131 Stroebel Protocols as a Possible Solution to Jurisdiction Problems 16.

132 Franco 2003 SA Merc LJ 28-38; Stroebel Protocols as a Possible Solution to Jurisdiction Problems 16; Smith 2002 SA Merc LJ 19-31; Mouton The Competence of the Foreign Representative in Cross-Border Insolvency Matters 32-51.

133 The principle of comity empowers any state or country to recognise the legislative, executive or judicial actions of another state or nation to, inter alia, protect its own citizens and other relevant persons in accordance with its international duties and principles of convenience. See Hilton v Guyot 1895159 US 113 163-164; Stroebel Protocols as a Possible Solution to Jurisdiction Problems 22; Smith and Boraine "Crossing Borders into South African Insolvency Law: From the Roman-Dutch Jurists to the UNCITRAL Model Law" 200210 American Bankruptcy Institute LR 135 177-187.

134 Deutsche Bank AG v Moser 1999 (4) SA 216 (C), for related discussion on the principles of convenience and equity. 
the discretion to recognise the appointment of foreign representatives in respect of cross-border insolvency proceedings. ${ }^{135}$ Moreover, the classification of property and persons (whether individuals or juristic persons) is crucially important for the purposes of determining the applicable common law rules in cross-border insolvency proceedings. ${ }^{136}$ With regard to movable property, the law that governs the individual or owner of the property determines the court and country where insolvency proceedings should be conducted. Thus, the court where the insolvent individual is domiciled has jurisdiction over his or her movable property under the common law rules for cross-border insolvency in South Africa. Accordingly, where the debtor is domiciled in a foreign country, the court order of his or her foreign domicile (lex domicilii) divests that debtor of his or her movables in South Africa. Consequently, a single concursus creditorum is automatically created and thereafter, all affected creditors irrespective of their place of domicile are entitled to claim their proceeds from the debtor's estate. ${ }^{17}$ This could suggest that the common law rules pertaining to the debtor's movable property employ the universalist approach since the sequestration order that is issued by a court of the debtor's domicile divests him or her of both local and foreign movable property wherever it is located. ${ }^{138}$ Thereafter, such movable property is vested in the trustee or appointed liquidator of the debtor's insolvent estate. Likewise, if a company or juristic person is liquidated, the foreign representatives of affected creditors must seek recognition from the court where such company or juristic person is located or has property before they can claim any movable property in respect thereof. ${ }^{139}$

With regard to immovable property, the common law rules pertaining to the law of the location of the debtor's property (lex situs or lex rei sitae) determine where cross-border insolvency proceedings will be conducted. ${ }^{14}$

135 Smith and Boraine 200210 American Bankruptcy Institute LR 178-180; Smith 2002 SA Merc LJ 24-32.

136 Mouton The Competence of the Foreign Representative in Cross-Border Insolvency Matters 32; Ras The Future of the Cross-Border Insolvency Act 42 of 2000 8-11.

137 Mouton The Competence of the Foreign Representative in Cross-Border Insolvency Matters 32-38; Ras The Future of the Cross-Border Insolvency Act 42 of 2000 8-11; Stroebel Protocols as a Possible Solution to Jurisdiction Problems 17; Smith 2002 SA Merc LJ 2431; Smith and Ailola 1999 SA Merc LJ 192-195; Ailola 2000 Stell LR 215-217.

138 Smith 2002 SA Merc LJ 24-29; Stroebel Protocols as a Possible Solution to Jurisdiction Problems 17; Ex parte Palmer NO: In re Hahn 1993 (3) SA 359 (C) 362 I-J; Trustee of Howse, Sons and Co $v$ Trustees of Howse, Sons and Co, Jocelyne $v$ Shearer and Hine 18843 SC 14 19, where it was, inter alia, stated that the insolvent's movable property follow the natural person (mobilia sequuntur personam), irrespective of where he or she is domiciled.

139 Smith and Boraine 200210 American Bankruptcy Institute LR 180-181; Donaldson v British SA Asphalte and Mfg. Co. Ltd 1905 TS 753 756-757; Smith 2002 SA Merc LJ 24-29; Stroebel Protocols as a Possible Solution to Jurisdiction Problems 17; Ex parte Palmer NO: In re Hahn 1993 (3) SA 359 (C) 362I-J; Trustee of Howse, Sons and Co v Trustees of Howse, Sons and Co, Jocelyne $v$ Shearer and Hine 18843 SC 14 19, where it was, inter alia, stated that the insolvent's movable property follow the natural person (mobilia sequuntur personam), irrespective of where he or she is domiciled.

140 Ras The Future of the Cross-Border Insolvency Act 42 of 2000 11; Olivier and Boraine 2005 CILSA 379-380; Smith and Boraine 200210 American Bankruptcy Institute LR 181; Lechner 2002 Arizona Journal of International and Comparative Law 980-981; Smith and Ailola 1999 SA Merc LJ 193-195; Smith 2002 SA Merc LJ 29-31; Mouton The Competence 
Notably, the common-law rules pertaining to the debtor's immovable property do not distinguish between individuals and juristic persons. Moreover, any foreign representatives of affected foreign companies or juristic persons must seek recognition in the relevant South African courts when such companies or juristic persons are liquidated. ${ }^{141}$ This shows that a foreign sequestration order against a debtor who has immovable property in a foreign country but is domiciled in South Africa has limited extra-territorial application under common law. Accordingly, all the representatives of foreign creditors are obliged to seek recognition in any South African court where the debtor has immovable property in South Africa before they could be allowed to prove their claims in respect of such property. Furthermore, such representatives have a positive duty to apply for recognition in the South African courts in accordance with the common law. In relation to this, all the relevant South African courts must adjudicate upon such cross-border insolvency cases based on comity, convenience and equity. ${ }^{142}$ Where such recognition is denied, the immovable property of the debtor will remain vested in the trustee of his or her insolvent estate. ${ }^{143}$

In addition to common law, South Africa also employs statutory regulation to curb cross-border insolvency challenges. For instance, although the Insolvency Act mainly deals with domestic insolvency matters, it grants the jurisdiction to hear both domestic and cross-border insolvency matters to any court that is located where the debtor owns property or businesses and/or where he or she is domiciled. ${ }^{144}$ This could indicate that cross-border insolvency matters involving a debtor who is domiciled in South Africa while he or she has creditors or property in foreign countries that are not designated under the Cross-Border Insolvency $\mathrm{Act}^{145}$ are settled in accordance with section 149(1) of the Insolvency Act. However, apart from section 149(1) of the Insolvency Act, no other specific provisions deal with the regulation of cross-border insolvency matters under the Insolvency Act. The Insolvency Act defines property to include all movable or immovable property, including contingent interests in property, of the insolvent debtor in South Africa at the time of sequestration as well as property acquired before rehabilitation. ${ }^{146}$ This definition excludes the debtor's contingent interests of a fidei commissary heir or legatee. Moreover, the definition does not expressly include the insolvent debtor's foreign-based property. However, no similar definition is found in the Cross-Border Insolvency Act. A similar approach, which fails to define the term "property", is employed in the UNCITRAL Model Law.

of the Foreign Representative in Cross-Border Insolvency Matters 35-40; Stroebel Protocols as a Possible Solution to Jurisdiction Problems 20-21.

141 Smith and Boraine 200210 American Bankruptcy Institute LR 181-182; Smith 2002 SA Merc LJ 29-31; Mouton The Competence of the Foreign Representative in Cross-Border Insolvency Matters 35-40; Stroebel Protocols as a Possible Solution to Jurisdiction Problems 16-21.

142 Khumalo International Response to the UNCITRAL Model Law 15-17; Smith and Boraine 200210 American Bankruptcy Institute LR 181-182; Smith "Some Aspects of South African Cross-Border Insolvency Relief: The Lehane Matter" 2016 PER 12-19.

143 Smith and Ailola 1999 SA Merc LJ 193-195.

$144 \mathrm{~S}$ 149(1) of the Insolvency Act.

$145 \mathrm{~S} 2(2)$

146 S 2; also see Smith and Boraine 200210 American Bankruptcy Institute LR 175. 
As stated above, ${ }^{147}$ apart from the Insolvency Act, related aspects of the winding up of companies and insolvency regulation in South Africa are dealt with under the Companies Act $1973^{148}$ and the Companies Act 2008. ${ }^{149}$ Nevertheless, these Acts do not expressly provide for the regulation of cross-border insolvency in South Africa.

The Cross-Border Insolvency Act is the main statute that regulates crossborder insolvency matters in South Africa. This Act is largely based on the UNCITRAL Model Law. ${ }^{151}$ For instance, the Cross-Border Insolvency Act applies where:

a) a foreign court or representative seeks assistance in South Africa, in relation to foreign cross-border insolvency proceedings (inward-bound request); or

b) South African assistance is requested by the courts or foreign representatives in a foreign country, in relation to cross-border insolvency proceedings under the South African insolvency laws (outward-bound request); or

c) foreign cross-border insolvency proceedings and the South African insolvency proceedings takes place concurrently in respect of the same debtor, or

d) creditors or other interested persons in a foreign country have requested to commence or take part in cross-border insolvency proceedings under the South African insolvency laws. ${ }_{13}^{152}$ Almost identical provisions are found in the UNCITRAL Model Law. ${ }^{153}$

Moreover, both the Cross-Border Insolvency Act ${ }^{154}$ and the UNCITRAL Model Law ${ }^{155}$ have similar definitions of key terms. Nevertheless, unlike the UNCITRAL Model Law, the reciprocity requirement somewhat indirectly restricts the application of the Cross-Border Insolvency Act, which stipulates that its provisions are only enforceable against the affected parties from countries that are designated by the Minister of Justice. ${ }^{156}$ Besides this, both the Cross-Border Insolvency Act ${ }^{157}$ and the UNCITRAL Model Law ${ }^{158}$

147 See remarks in fn 125.

148 Ss 344(g); 354-366 and related provisions under Chapter XIV.

149 Ss 79-81 and Schedule 5, item 9.

150 Ras The Future of the Cross-Border Insolvency Act 42 of 2000 12-13; Mouton The Competence of the Foreign Representative in Cross-Border Insolvency Matters 24

151 See related remarks in par 2 and 4 above.

152 S 2(1) read with ss 9-24 of the Cross-Border Insolvency Act; Smith and Boraine 200210 American Bankruptcy Institute LR 187-205; Mouton The Competence of the Foreign Representative in Cross-Border Insolvency Matters 42-51; Stroebel Protocols as a Possible Solution to Jurisdiction Problems 24-26; Olivier and Boraine 2005 CILSA 379-388; Smith and Ailola 1999 SA Merc LJ 206-207; Clift 2004 Tulane Journal of International Law and Comparative Law 333-334.

153 Article 1(1) of the UNCITRAL Model Law.

154 S 1.

55 Article 2.

156 S 2(2)(a) and (b). See further Mouton The Competence of the Foreign Representative in Cross-Border Insolvency Matters 42-51; Olivier and Boraine 2005 CILSA 379-388; Smith and Boraine 200210 American Bankruptcy Institute LR 176, 186-205; Franco 2003 SA Merc LJ 33-42.

157 Ss 3-8. 
recognises the: (a) establishment of competent courts in different countries, (b) insolvency-related international obligations between different countries, (c) need for additional assistance to foreign representatives, (d) public policy exceptions to the enforcement of cross-border insolvency laws, and (e) need to promote uniformity when interpreting such laws. Additionally, both the Cross-Border Insolvency Act ${ }^{159}$ and the UNCITRAL Model Law ${ }^{160}$ grant foreign representatives and creditors of the debtor access to the relevant courts and various rights to enable them to commence and effectively participate in cross-border insolvency proceedings. Similar provisions on the recognition of foreign proceedings and relief for all affected creditors are also found in the Cross-Border Insolvency Act ${ }^{161}$ and the UNCITRAL Model Law. $^{162}$ Likewise, the Cross-Border Insolvency Act $^{163}$ and the UNCITRAL Model Law ${ }^{164}$ promote different forms of communication and cooperation between trustees, liquidators, curators, judicial managers, local courts, foreign courts, foreign representatives and other relevant stakeholders that are involved in cross-border insolvency proceedings. Over and above, almost identical provisions on the commencement, coordination and recognition of concurrent insolvency proceedings in South Africa and other countries are enumerated in the Cross-Border Insolvency Act $^{165}$ and the UNCITRAL Model Law. ${ }^{166}$ However, notwithstanding these positive developments, both the Cross-Border Insolvency Act and the UNCITRAL Model Law do not define the term "property". This was probably left to the courts to interpret. Nonetheless, one could conclude that the term "property" includes both movable and immovable property of the insolvent debtor that is located in his or her country of domicile and/or other foreign countries.

\section{SELECTED FLAWS AND CHALLENGES ASSOCIATED WITH CROSS-BORDER INSOLVENCY REGULATION IN SOUTH AFRICA}

Although the adoption of the UNCITRAL Model Law and its incorporation into the Cross-Border Insolvency Act in 2003 is commendable, this Act has not yet come into force to date. This follows the fact that the Cross-Border Insolvency Act will only come into force when the Minister of Justice designates the countries to which it will apply. ${ }^{167}$ This designation requirement is worsened by the fact that the Minister of Justice will only designate countries that are willing to reciprocally recognise the provisions of the Cross-Border Insolvency Act in respect of cross-border insolvency proceedings. Notably, no such reciprocity requirement is provided under the UNCITRAL Model Law. To date, no countries have been designated by the

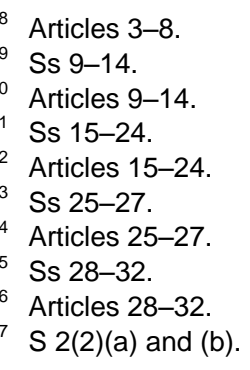


Minister of Justice and the Cross-Border Insolvency Act has remained redundant since 2003. This, unfortunately, entails that South Africa has a dual approach regarding cross-border insolvency regulation in that: (a) representatives from countries that are going to be designated are regulated by the Cross-Border Insolvency Act; and (b) common law regulates representatives from non-designated countries. ${ }^{168}$ Put differently, although the reciprocity requirement is also employed in Mexico, the British Virgin Islands, Romania and Mauritius, it has been too restrictively applied in South Africa because the Cross-Border Insolvency Act only covers designated countries. ${ }^{169}$ This restrictive reciprocity requirement could have negatively affected the application of the Cross-Border Insolvency Act.

Furthermore, the aforesaid dual approach has been sometimes confusingly and inconsistently enforced to regulate cross-border insolvency matters in South Africa. Such confusion is usually found in respect of the recognition of foreign creditors and foreign representatives as well as the enforcement of the common law position regarding the debtor's movable or immovable property that is located in South Africa and/or other foreign countries. ${ }^{170}$ The confusion is exacerbated by the fact that the Cross-Border Insolvency Act does not indicate what constitutes a debtor's property for the purposes of cross-border insolvency proceedings. ${ }^{171}$ Moreover, the current dual approach may give rise to multiple and different cross-border insolvency proceedings in countries other than South Africa contrary to the Cross-Border Insolvency Act and the UNCITRAL Model Law's cooperation and uniformity objectives.

The Cross-Border Insolvency Act does not clearly stipulate penalties or measures that could be employed against any insolvent debtors that evade or tries to evade their debts by destroying or selling property that belongs to their estate. This position could have influenced in part by the fact that the Cross-Border Insolvency Act employs the so-called Model Soft Law Approach, which the UNCITRAL Model Law also follows. The Model Soft Law Approach allows countries that adopt the UNCITRAL Model Law to discretionally incorporate some changes to it in order to resolve their domestic problems. ${ }^{173}$ Unlike hard law, the Model Soft Law Approach is flexible and simple to enforce since the enacting country has the freedom to adopt its own version of the UNCITRAL Model Law. ${ }^{174}$ Nonetheless, the UNCITRAL Model Law could have left out the enactment of possible penalties and/or measures that could be taken against unscrupulous debtors to the enacting countries. In this regard, the South African policymakers

168 Olivier and Boraine 2005 CILSA 379-380; Clift 2004 Tulane Journal of International Law and Comparative Law 333-334; Ras The Future of the Cross-Border Insolvency Act 42 of 2000 19-35.

169 Khumalo International Response to the UNCITRAL Model Law 13-28.

170 Loubser 2007 SA Merc LJ 125-139.

171 Smith and Boraine 200210 American Bankruptcy Institute LR 175.

172 See the preamble of the UNCITRAL Model Law; preamble of the Cross-Border Insolvency Act.

173 Anderson 2004 Australian Year Book of International Law 2-7, 9-11.

174 Anderson 2004 Australian Year Book of International Law 2, 4-5; Mason "Cross-border Insolvency and Legal Transnationalisation" 2012 International Insolvency Review 105112 125. 
failed to effectively utilise the Model Soft Law Approach to enact specific anti-cross-border insolvency penalties and/or measures against unscrupulous debtors in the Cross-Border Insolvency Act.

Having two statutory insolvency regimes namely the Insolvency Act for domestic insolvency matters and the Cross-Border Insolvency Act exclusively for foreign-related insolvency matters could have impeded the statutory regulation of cross-border insolvency matters in South Africa since the latter Act is still to come into force. Consequently, there is still confusion and restricted legal certainty regarding the application of the Cross-Border Insolvency Act. The statutory efforts to curb cross-border insolvency challenges are compounded by the fact that section 149(1) of the Insolvency Act does not expressly provide for the regulation of cross-border insolvency.

Moreover, only South African High Courts have the jurisdiction to hear cross-border insolvency cases under the Cross-Border Insolvency Act. ${ }^{175}$ This could be too restrictive and may give rise to delays and increased backlogs in the settlement of cross-border insolvency matters in South Africa. Furthermore, the South African High Courts have limited jurisdiction in foreign proceedings under the Cross-Border Insolvency Act in that foreign representatives merely restrict their authority to the purpose of application. ${ }^{17}$ Perhaps, powers that are more discretionary should have been given to the relevant courts to enable them to effectively enforce the provisions of the Cross-Border Insolvency Act.

\section{CONCLUDING REMARKS}

The enactment of the Cross-Border Insolvency Act was a positive move towards the adoption of the UNCITRAL Model Law in South Africa. Moreover, the enactment of the Cross-Border Insolvency Act was also an unequivocal attempt on the part of the policymakers to combat cross-border insolvency challenges in South Africa. Nevertheless, several flaws are still embedded in the current South African cross-border insolvency regulation. For instance, there is still confusion and uncertainty regarding the application of the Cross-Border Insolvency Act. In this regard, it is submitted that the policy makers should consider fusing the provisions of the Cross-Border Insolvency Act and the Insolvency Act in order to enact a single adequate legislation that deals with insolvency matters at national and international levels. This could enhance legal certainty and minimise the aforesaid confusion. Furthermore, the enactment of one legislation to deal with national and cross-border insolvency matters could curb possible challenges of over regulation that occurs when several statutes are enacted to regulate the same conduct.

Moreover, the Cross-Border Insolvency Act should be amended to remove the reciprocity and designation requirement that is contrary to the UNCITRAL Model Law ${ }^{177}$ to enhance the combating of cross-border insolvency problems in South Africa. This could enable South Africa to fully

\footnotetext{
S 4 of the Cross-Border Insolvency Act.

176 S 10 of the Cross-Border Insolvency Act.

177 See related comments in par 6 above.
} 
implement the relevant provisions of the UNCITRAL Model Law. South Africa should also consider signing and ratifying cross-border insolvency protocols, treaties and/or conventions to enhance cross-border insolvency regulation in South Africa. In other words, such protocols, treaties and/or conventions could further supplement the statutory regulation of crossborder insolvency in South Africa.

Notwithstanding the fact that the Cross-Border Insolvency Act was probably meant to be a soft law, it should be amended to enable the High Courts, the Supreme Court and the Constitutional Court to have more discretionary and unrestricted powers to hear cross-border insolvency matters in South Africa.

Unlike the UNCITRAL Model Law, ${ }^{178}$ the Cross-Border Insolvency Act is applicable to both natural and juristic persons (including banks and insurance companies). In this regard, it is submitted that the Cross-Border Insolvency Act should be amended to enact provisions that expressly exempt banks, insurance companies and other entities from the application of its provisions in line with the UNCITRAL Model Law. The Cross-Border Insolvency Act should also be amended to enact adequate provisions for penalties and/or measures that could be employed against insolvent debtors that evade or tries to evade their debts by selling property, which belongs to their estate. Lastly, the author concurs with Smith and Boraine ${ }^{179}$ who correctly argue that section 149(1) of the Insolvency Act should be amended to clearly provide that creditors and their foreign representatives have access to the courts as provided in both the UNCITRAL Model Law ${ }^{180}$ and the Cross-Border Insolvency Act.

178 Article 1(2) of the UNCITRAL Model Law; see related comments in par 4 above.

179 Smith and Boraine 200210 American Bankruptcy Institute LR 174.

180 See Chapter II.

181 See Chapter 2. 